\title{
Impact of the Speed of Flat of a Typical Carding Machine on the Quality of Carded Sliver and 40 Ne Yarn
}

\author{
Zubair Bin Sayed1 ${ }^{*}$, Naba Afrose ${ }^{2}$, Shabrina Kabir ${ }^{3}$ \\ ${ }^{1}$ Department of Textile Engineering, Port City International University, Chittagong, Bangladesh \\ ${ }^{2}$ Department of Textile Engineering, Ahsanullah University of Science and Technology, Dhaka, Bangladesh \\ ${ }^{3}$ Department of Textile Machinery Design and Maintenance, Bangladesh University of Textile, Dhaka, Bangladesh \\ Email: ^zubinsayeed@gmail.com, Naba.afrose@gmail.com, shimashabrina067@gmail.com
}

How to cite this paper: Sayed, Z.B. Afrose, N. and Kabir, S. (2021) Impact of the Speed of Flat of a Typical Carding Machine on the Quality of Carded Sliver and $40 \mathrm{Ne}$ Yarn. Journal of Textile Science and Technology, 7, 66-76.

https://doi.org/10.4236/jtst.2021.71006

Received: January 17, 2021

Accepted: February 23, 2021

Published: February 26, 2021

Copyright $\odot 2021$ by author(s) and Scientific Research Publishing Inc. This work is licensed under the Creative Commons Attribution International License (CC BY 4.0).

http://creativecommons.org/licenses/by/4.0/

\begin{abstract}
The carding cycle affects the sliver quality and the subsequent yarn attributes since it is the main sliver formation step. Processing parameters assume a significant part in affecting the nature of the eventual outcome in any sorts of production. In the case of carding machine, a higher production rate makes the operation more sensitive. And this will cause degradation in product quality. So optimization of speed is the talk of the town in spinning field [1]. Extreme higher speed can prompt fiber harm and unnecessary neps generation will corrupt the end result. Again lower speed will lessen the production rate which isn't reasonable. So we need to discover the ideal speed which will be advantageous to both product quality and production rate. In carding machine, real operational activity happens between flats and cards [1]. From an ordinary perspective, high produce able cards generates higher level of speed. Speed of the cards impacts the carding cycle and the nature of the yarn and in practical point of view, flat's level of speed is advanced and optimized. The aim of the project was to find out the optimum flat speed in the context of yarn quality. $40 \mathrm{Ne}$ cotton yarns were produced with the slivers manufactured at different flat speeds such as $240,260,280,300$ and $320 \mathrm{~mm} / \mathrm{min}$. The quality parameters of slivers and yarns were tested and analyzed.
\end{abstract}

\section{Keywords}

Flat, Carding Machine, Carded Sliver, English Count (Ne), Yarn

\section{Introduction}

Since carding is a complex operation-it includes a number of parameters and 
factors-and grasps unique advancements, improvement of the carding efficiency has been made conceivable by the improvements in some scientific fields, for example, hardware, materials science, robotization and control.

These improvements permit a few different ways for expanding carding profitability. The carding quality is essentially decided in the region of the cylinder. Here, the circulating flat is of specific significance. With an ideal number of level bars, it is liable for cleaning just as extricating neps and short filaments. This occupation is doled out to the pre-checking region with its cleaning and checking components. As a regulation: The higher the pre opening, the more intensive the carding operation, which results in expanded production. The motivation behind speedy carding is to expand the card efficiency without diminishing operation quality, or even improving it. It had been believed that increased carding speed would expand fiber breakage, however there is no proof why fiber breakage should be enlarged as card speed expands (Atkinson, 1986) [2]. It was important to increase the rate of production of the carding machine in light of the fact that new advancements with significantly higher production levels were begun to be executed, implemented and introduced.

Carding activity can be depicted as the combing of fibers between successive surfaces, which convey a number of angular wires (card clothing) focused on restricting headings, opposite direction when their relative speed is more prominent than zero. What individualizes the fibres and offers parallelism to the fiber mass flow is the connection between the saw-tooth cloth covering of cylinder, the flats/laborers furthermore, the fiber mass (Lawrence, et al., 2000) [3]. In the point of view of Deussen (1992) [4], fiber length picks up its significance as the main quality boundary for three reasons: 1) Yarn count that can be spun from cotton depends on its fiber length. With different properties being equivalent with, better yarns can commonly be spun from the longer length cottons. 2) At the equivalent count, yarns spun from longer length cottons, other fiber properties being equivalent, are more grounded than those from smaller length cottons. 3) Fiber length has an immediate bearing on yarn strength in light of the fact that the longer the filaments in yarn, the more noteworthy the quantity of purposes of contact and attachment among them, and therefore expanded yarn strength. Artzt (2000) [5] revealed that in the light of the present information, compact spinning produces yarns which generates a prevalent ring yarn. It is accordingly actually another brand new spinning operation, in spite of the fact that the yarn looks a lot of like ring yarn. Spinning devoid of without turning triangle results in uniform fiber reconciliation pressure through the yarn cross-segment, and subsequently in various conduct in downstream operation.

In compact spinning, the filaments are compacted into a hollow sliver after a basically pressure free drafting operation inside a compacting zone and they are twisted after the pinching point as a reduced intensified sliver. As in the exemplary spinning triangle, fringe filaments are exterminated. In the current work, the influence of the speed of flat of the quality of final yarn was studied. Research works have been carried out time to time on the influence of different parame- 
ters over the sliver and yarn quality. Nadim Hossain, et al. [6] in 2017, worked on effect of taker-in speed of card on the quality of ring spun yarns yarns which generates a prevalent ring yarn. It is accordingly actually another brand new spinning operation, in spite of the fact that the yarn looks a lot of like ring yarn. Spinning devoid of without turning triangle results in uniform fiber reconciliation pressure through the yarn cross-segment, and subsequently in various conduct in downstream operation.

In compact spinning, the filaments are compacted into a hollow sliver after a basically pressure free drafting operation inside a compacting zone and they are twisted after the pinching point as a reduced intensified sliver. As in the exemplary spinning triangle, fringe filaments are exterminated. In the current work, the influence of the speed of flat of the quality of final yarn was studied. Research works have been carried out time to time on the influence of different parameters over the sliver and yarn quality.

\section{Material \& Methods}

\subsection{Materials}

Commonwealth of Independent States (CIS) cotton originated from Uzbekistan was utilized as the raw material to plan tests of sliver and yarn. The raw cotton fiber properties were tested with the assistance of USTER EVENNESS TESTER-5 and USTER AFIS PRO 2 as per the standard testing conditions appeared in Table 1 . Sliver fineness $\mathrm{Ne} 0.12$ and one sort of yarn count $(\mathrm{Ne} 40)$ were utilized as tested sample. Both were delivered by Motin Spinning Mills Ltd.

\subsection{Methods}

\subsubsection{Carding Process}

In this experiment, the flat of carding machine (TC 03) was driven at five different speeds, that is, 200, 240, 280, 320, and $360 \mathrm{~mm} / \mathrm{min}$, by keeping all other parameters unchanged. The process parameters of the carding machine are given in Table 2. Five carded slivers were delivered for every level of flat speed to take care of the output of breaker draw frame.

\subsubsection{Spinning Process}

A ring outline machine, named Lakshmi, was utilized for creating yarn. $\mathrm{Ne} 40$ checked yarn was created from $\mathrm{Ne} 0.70$ wandering. In ring frame, roving was placed on same shafts for every flat speed. Significant cycle parameters for the spinning procedure are provided in Table 3.

Table 1. Properties of raw cotton.

\begin{tabular}{cc}
\hline Properties & Value \\
\hline Raw material & $100 \%$ cotton \\
Staple length & $29-30 \mathrm{~mm}$ \\
Micronaire & 3.8 \\
Raw material origin & Uzbekistan \\
\hline
\end{tabular}


Table 2. Process parameters of carding machine.

\begin{tabular}{cccc}
\hline Technical Data & Settings & Technical Data & Settings \\
\hline Sliver hank & $340-465$ grain/6 yds. & Feed roller to taker-in & $0.65 \mathrm{~mm}$ \\
Feed roller diameter & $100 \mathrm{~mm}$ & Taker-into cylinder & $0.22 \mathrm{~mm}$ \\
Taker in diameter & $172.5 \mathrm{~mm}$ & Back stationary flat to cylinder & $0.55 \mathrm{~mm}, 0.55 \mathrm{~mm}, 0.45 \mathrm{~mm}$ \\
Taker in speed & $1162 \mathrm{rpm}$ & Revolving flat to cylinder & $0.30 \mathrm{~mm}, 0.275 \mathrm{~mm}, 0.25 \mathrm{~mm}, 0.25$ \\
& 1) $34,10^{\circ}$ & Front stationary flat to cylinder & $0.20 \mathrm{~mm}$ \\
Taker in PPSI & 2) $163,10^{\circ}$ & Cylinder to doffer & $0.55 \mathrm{~mm}, 0.55 \mathrm{~mm}$ \\
& 3) $210,10^{\circ}$ & Doffer. to take of Roller & $0.125 \mathrm{~mm}$ \\
Cylinder diameter & $1287 \mathrm{~mm}$ & Take-off roller to delivery roller & $0.15 \mathrm{~mm}$ \\
Cylinder speed & $561 \mathrm{rpm}$ & Delivery speed & $0.25 \mathrm{~mm}$ \\
Cylinder PPSI & $950,40^{\circ}$ & Doffer dia. & $190 \mathrm{~m} / \mathrm{min}$ \\
No. of flats & 84 & Doffer PPSI & $700 \mathrm{~mm}$ \\
No. of flats in action & 30 & Doffer speed & $483,30^{\circ}$ \\
Flat PPSI & $525,5^{\circ}$ & Flat speed & $($ Around $180 \mathrm{~m} / \mathrm{min})$
\end{tabular}

Table 3. Important parameters of spinning process.

\begin{tabular}{cc}
\hline Name of the Parameters & 40 Ne Yarn \\
\hline Drawn sliver hank & $0.12 \mathrm{Ne}$ \\
Roving hank & $0.9 \mathrm{Ne}$ \\
Twist per inch & 22.35 \\
Ring frame speed (RPM) & 17,500 \\
Drafting arrangement (ring frame) & 3 over 3 \\
Draft (ring frame) & 44.44 \\
Doubling (breaker draw frame) & 6 \\
Doubling (finisher draw frame) & 5 \\
\hline
\end{tabular}

\subsubsection{Testing of Samples}

The flat speed variation has an effect on the end product. Short fibres content, sliver unevenness, yarn unevenness properties, thin places, thick places, neps, hairiness and yarn strength are influenced by the flat speed.

Neps: A NEP can be defined as a small knot (or cluster) of entangled fibres consisting either entirely of fibres (i.e., a fibre nep) or of foreign matter (e.g. a seed-coat fragment) entangled with fibres. Neps are created when fibres become tangled in the process of harvesting, ginning and other operations [7].

Neps content is measured in AFIS. The unit of neps content is neps content per gram in the material.

The proportion of neps has an extremely great influence on the parameters:

Yarn strength, yarn evenness, yarn hairiness and handle of the product.

Neps Removal Efficiency (NRE\%): The neps removal efficiency depends on 
the neps fed to the card. If we feed more neps, then the neps removal efficiency shall be high. What is more important is the neps level in the outgoing material [7].

$$
\begin{aligned}
& \text { Neps removal efficiency } \\
& =\frac{\text { Neps content of card mat }- \text { Neps content of card sliver }}{\text { Neps content of card mat }} \times 100 \%
\end{aligned}
$$

Short Fibre Content by Number: The short fibre by number is the percent of all the fibres in a cotton sample that are normally shorter than 0.5 inches or 12.7 $\mathrm{mm}$ [8]. The proportion of short fibres has an extremely great influence on the parameters are:

Spinning limit, yarn strength, yarn evenness, handle of the product, yarn hairiness, productivity, neps.

Unevenness: Unevenness deals with the variation in yarn fineness. This is the property, commonly measured as the variation in mass per unit length along the yarn. For a complete analysis of the quality of fibre assembly, along with mass diagram, a numerical value of mass variation is also necessary. Mathematically it is done by The irregularity or unevenness (U\%) and the co-efficient of variation (CV\%) [9].

Imperfection Index (IPI): Imperfections are considered as frequently occurring faults and are dependent on the fibre quality of the raw material. The conditions of the production machinery strongly influence the amount of the imperfections in the yarn. The total imperfection of a yarn is simply expressed by imperfection index (IPI). The sensitivity settings for the detection of imperfections are $-50 \% / \mathrm{km}$ for thin places, $+50 \% / \mathrm{km}$ for thick places and $+200 \% / \mathrm{km}$ for neps [9].

Count Strength Product (CSP): It is a number which is derived by multiplication of count \& lea strength (in lbs.). The higher value represents the better yarn strength.

i.e. C.S.P. $=$ Strength of yarn in pound (lbs.) $\times$ Count in English system $(\mathrm{Ne})$ [10].

\section{Result \& Discussion}

\subsection{Effect of Flat Speed on Carded Sliver}

\subsubsection{Graphical Representation of Neps Content per Gram and Neps Removal Efficiency (NRE\%)}

The left graph of Figure 1 indicates the variation of neps content in the carded sliver due to variation in flat speed of carding machine.

By observing the graph, we can say that the variation in the flat speed has an effect on the variation of the neps content per gram of card sliver. When flat speed is increased, more number of flat comes to the contact with fibre treatment operation. So the increase of flat speeds reduces the neps content per gram in the card sliver.

In the graph, we see that at flat speed $240 \mathrm{~mm} / \mathrm{min}$ neps content per gram was 

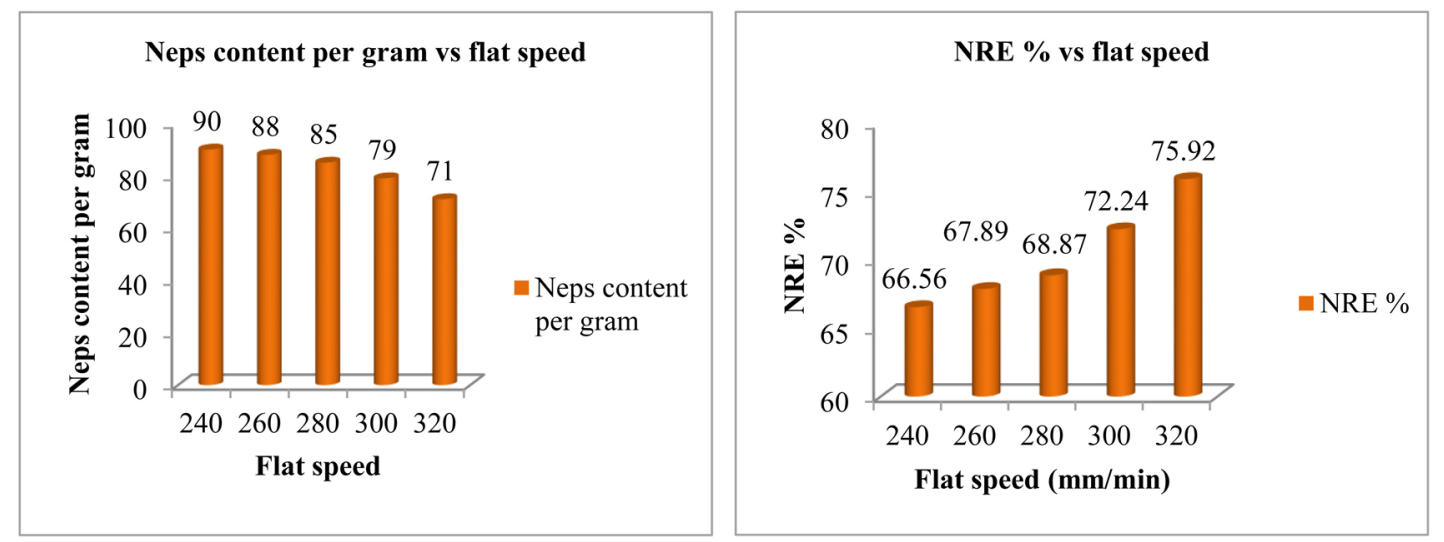

Figure 1. Effect of flat speed on neps content per gram and neps removal efficiency (NRE \%) of card sliver.

90 whereas at flat speed $320 \mathrm{~mm} / \mathrm{min}$ neps content per gram was 71 . So we may conclude that with the increase of flat speed neps content per gram of card sliver is reduced.

Second graph of Figure 1 indicates the variation of NRE\% in the carded sliver due to variation in flat speed of carding machine.

In the graph, we see that at flat speeds $240 \mathrm{~mm} / \mathrm{min}, 260 \mathrm{~mm} / \mathrm{min}, 280 \mathrm{~mm} / \mathrm{min}$, $300 \mathrm{~mm} / \mathrm{min}$ and $320 \mathrm{~mm} / \mathrm{min}$, the NRE\% are $66.56 \%, 67.89 \%, 68.87 \%, 72.24 \%$ and $75.92 \%$ respectively which is an increasing trend.

From the graph, we can say that the variation in the flat speed does have an effect on the variation of the NRE\% of card sliver. When flat speed is increased, more number of flat comes to the contact with fibre treatment operation. So the increase of flat speeds leads to increase in the NRE\% of the card sliver.

\subsubsection{Graphical Representation of Short Fibre Content by Number and Seed-Coat Nep Count}

The above left handed graph of Figure 2 shows the variation of short fibre content by number in the carded sliver due to variation in flat speed of carding machine.

Short fibres can only be eliminated if they are pressed into and retained in the clothing. Only the flats can be considered in this context. Short fibres offer less surface to the clothing of the main cylinder, they therefore remain caught in the flats clothing, are pressed into it and leave the machine in the flat stripping. As the flat speed is increased, more numbers of flats are cleaned of adhering short fibres by fast rotating brushes.

It may conclude from the graph that the variation in the flat speed has an effect on the short fibre content of card sliver and it shows a decreasing trend.

The above right sided graph of Figure 2 shows the variation of nep count in the carded sliver due to variation in flat speed of carding machine.

From the graph, we see that at flat speed 240, 260, 280, 300 and $320 \mathrm{~mm} /$ min the corresponding nep count of card sliver are 10, 5, 4, 3 and 1 respectively which is a decreasing trend. The increase of flat speed increases the finer neps content. 

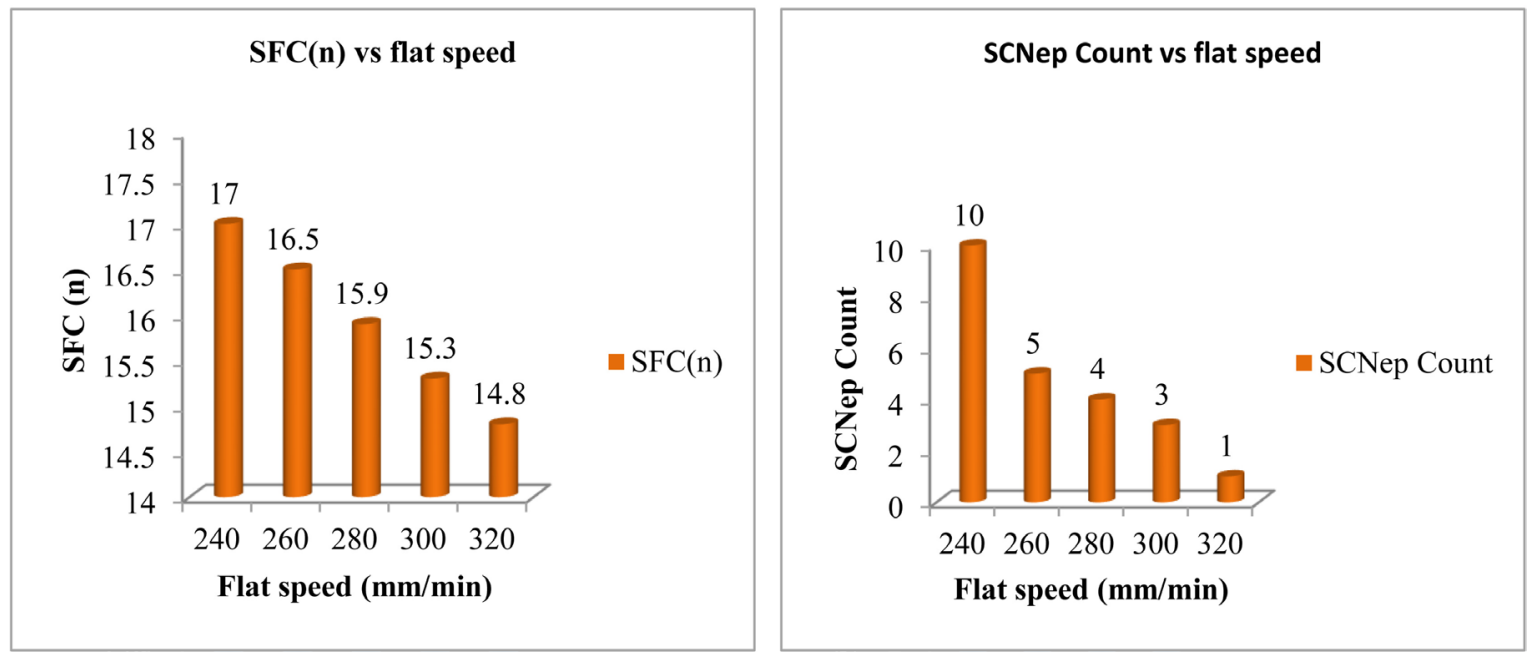

Figure 2. Effect of flat speed on SFC and SCN of carded sliver.

\subsubsection{Graphical Representation of Evenness and Co Efficient of Variance (CV\%)}

From Figure 3 the first graph shows that with the increase of flat speed the irregularity of card sliver reduces.

From the graph, it was observed that at flat speed 240, 260, 280, 300 and 320 $\mathrm{mm} / \mathrm{min}$ the corresponding $\mathrm{U} \%$ of card sliver are 3.56, 3.01, 2.71, 2.51 and 2.14 respectively which is a decreasing trend.

The increase of flat speed reduces the neps content and short fibre content. Therefore the degree of parallelization of fibre becomes higher because of better carding action also take place. Hence, the increase of flat speed reduces the irregularity of card sliver.

The graph shows that with the increase of flat speed the irregularity of card sliver marginally decreases.

In the second graph of Figure 3, it was notified that at flat speed 240, 260, 280, 300 and $320 \mathrm{~mm} / \mathrm{min}$ the CV\% are 4.44, 4.02, 3.91, 3.44 and 3.02 respectively which is a decreasing trend.

The increase of flat speed reduces the neps content and short fibre content. Therefore the degree of parallelization of fibre becomes higher because of better carding action. Hence, the increase of flat speed reduces the irregularity of card sliver.

\subsection{Effect of Flat Speed on 40 Ne Cotton}

\subsubsection{Graphical Representation of Unevenness (U\%) and Co Efficient of Variance (CV\%)}

From the first part of Figure 4 it is much more observable that yarn unevenness decreases with an increase in the card flat speed. As the card flat speed is increased from $240 \mathrm{~mm} / \mathrm{min}$ to $320 \mathrm{~mm} / \mathrm{min}$, there is a steady decrease in the yarn unevenness from 13.31 at flat speed $240 \mathrm{~mm} / \mathrm{min}$ to 11.52 at flat speed 320 $\mathrm{mm} / \mathrm{min}$. It is evident from the decreasing trend that the yarn unevenness is inversely proportional to the card flat speed. 

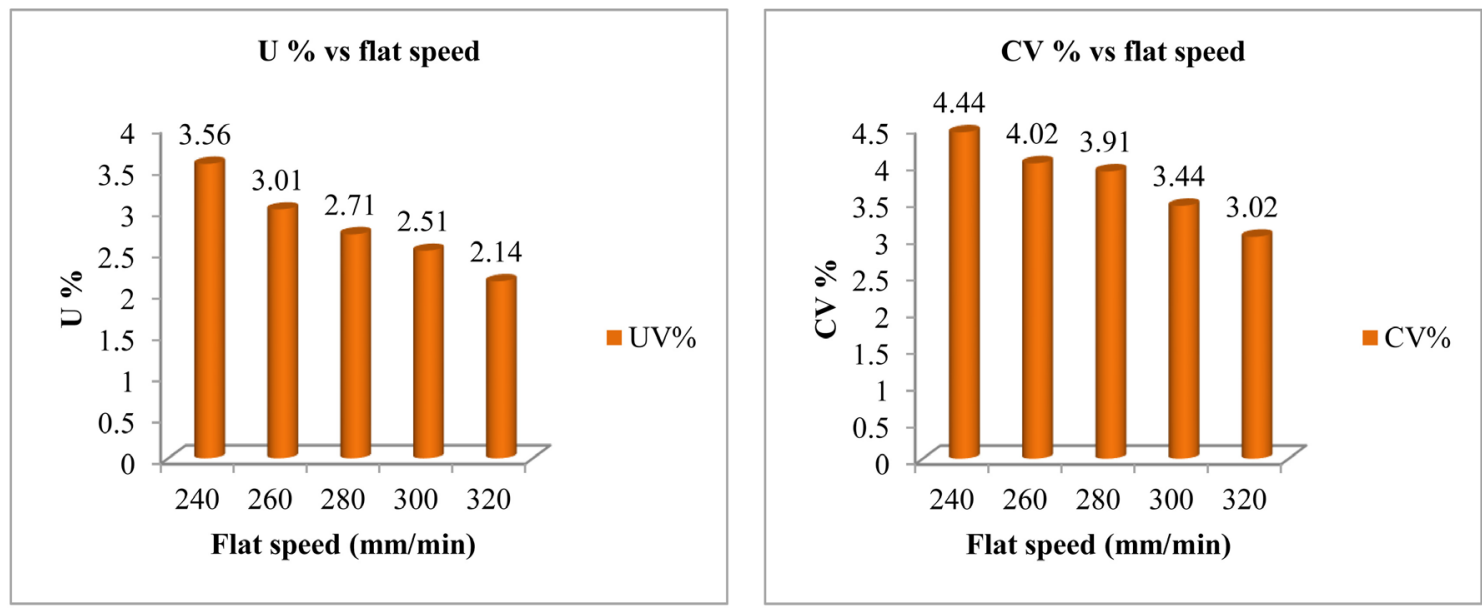

Figure 3. Effect of flat speed on $\mathrm{U} \%$ and $\mathrm{CV} \%$ of card sliver.
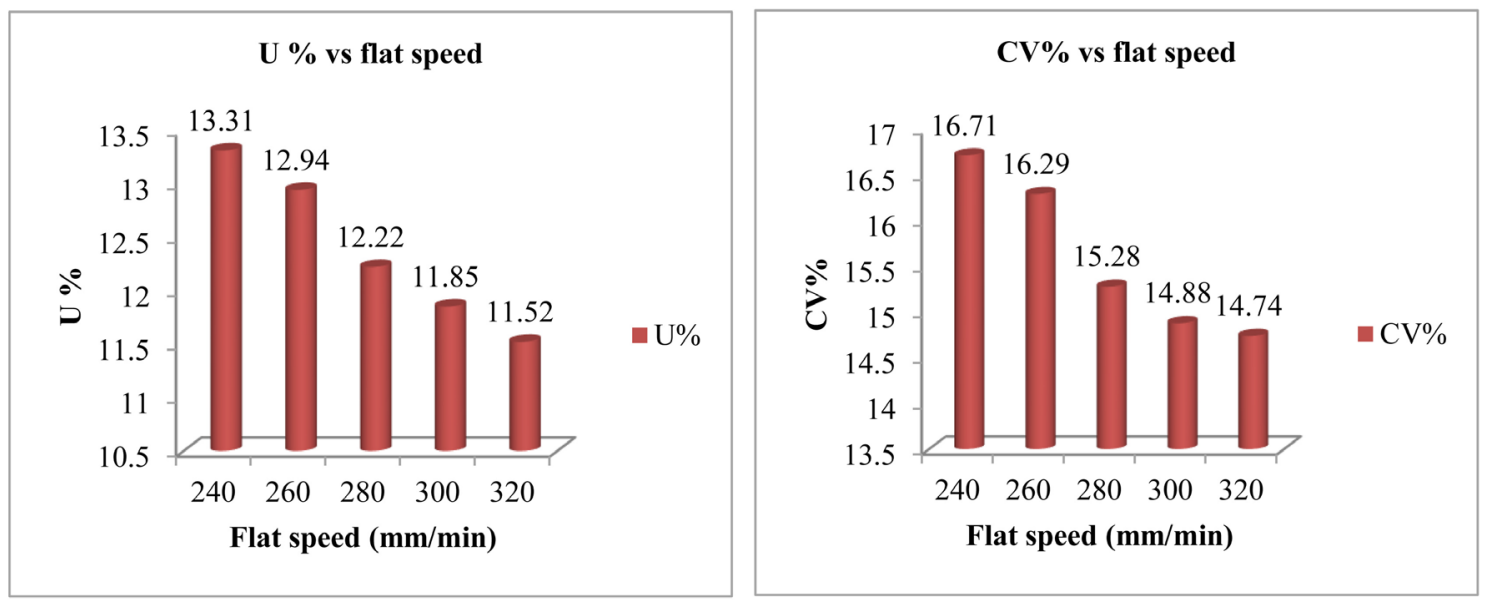

Figure 4. Effect of flat speed on U\% and CV\% of $40 \mathrm{Ne}$ cotton.

Second part of Figure 4 makes it clear that yarn CV\% decreases with an increase in the card flat speed. As the card flat speed is increased from 240 $\mathrm{mm} / \mathrm{min}$ to $320 \mathrm{~mm} / \mathrm{min}$, there is a steady decrease in the yarn CV\% from 16.71 at flat speed $240 \mathrm{~mm} / \mathrm{min}$ to 14.74 at flat speed $320 \mathrm{~mm} / \mathrm{min}$. It is evident from the decreasing trend that the yarn $\mathrm{CV} \%$ is inversely proportional to the card flat speed.

Hence, it can be said that the increase of flat speed reduces the co-efficient of variation of yarn.

\subsubsection{Graphical Representation of Thick Places $(+50 \% / \mathrm{km})$ and Thin Places $(+50 \% / \mathrm{km})$}

In the first graph of Figure 5, it was observed that at flat speed 240, 260, 280, 300 and $320 \mathrm{~mm} / \mathrm{min}$ thick places $+50 \%$ are $201.4,183,172,164.4$ and 150 respectively which is a decreasing trend.

We know that the amount of short fibres and neps content are proportionally related with the quality parameters of yarn (CV\%, thick places, thin places, neps and strength). Graphs for short fibre content and neps content showed less 


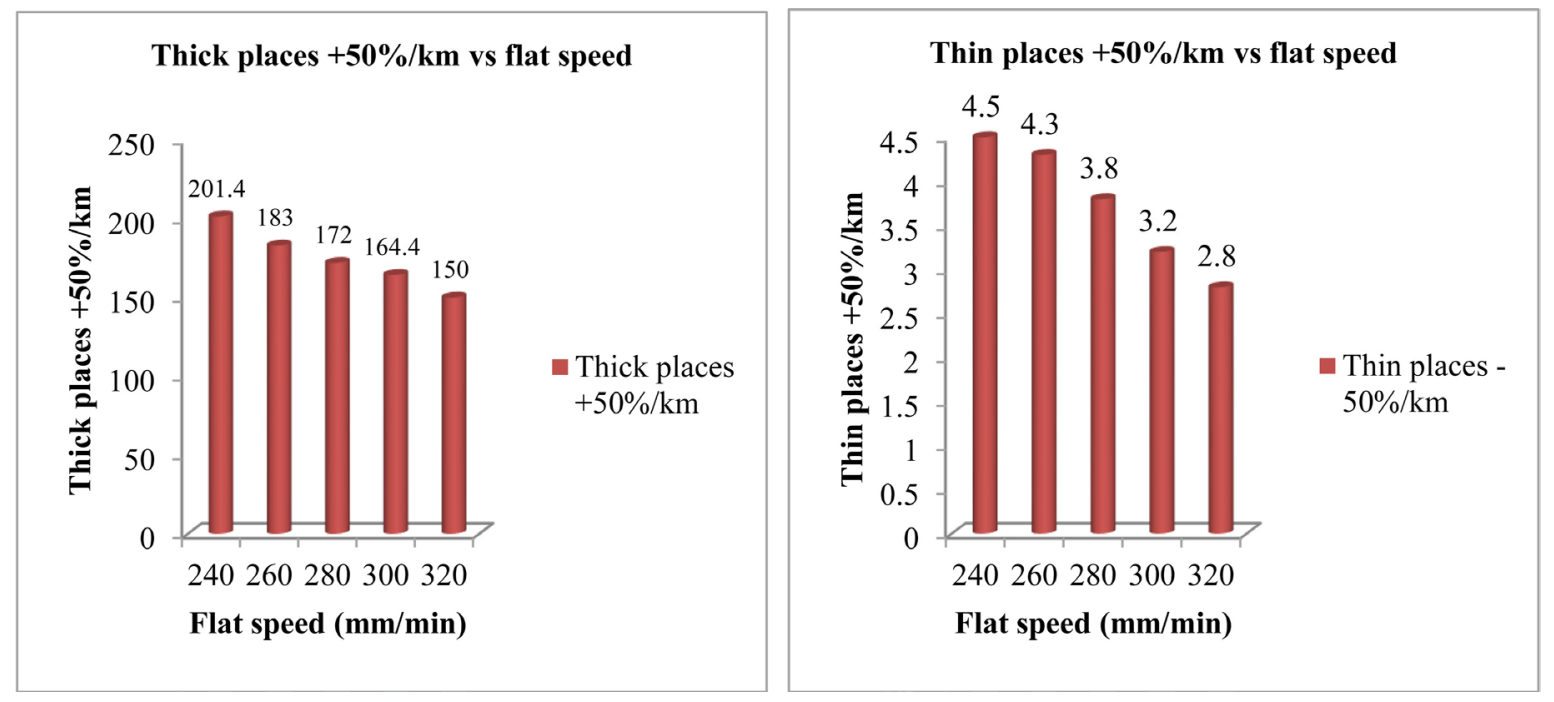

Figure 5. Effect of flat speed on thick places $(50 \% / \mathrm{km})$ and thin places $(50 \% / \mathrm{km})$ of $40 \mathrm{Ne}$ cotton.

removal of neps and short fibres at flat speed $240 \mathrm{~mm} / \mathrm{min}$ than $320 \mathrm{~mm} / \mathrm{min}$. As a result, less removal of short fibres and neps at flat speed $200 \mathrm{~mm} / \mathrm{min}$ are mainly responsible for higher number of thick places where as flat speed 320 $\mathrm{mm} / \mathrm{min}$ gives minimum number of thick places due to removal of higher number of short fibres and neps.

In the second graph of Figure 5, it was notified that at flat speed 240, 260, 280, 300 and $320 \mathrm{~mm} / \mathrm{min}$ thin places $-50 \%$ are $4.5,4.3,3.8,3.2$ and 2.8 respectively which is a decreasing trend.

We know that the amount of short fibres and neps content are proportionally related with the quality parameters of yarn (CV\%, thick places, thin places, neps and strength). Graphs for short fibre content and neps content showed less removal of neps and short fibres at flat speed $240 \mathrm{~mm} / \mathrm{min}$ than $320 \mathrm{~mm} / \mathrm{min}$. As a result, less removal of short fibres and neps at flat speed $200 \mathrm{~mm} / \mathrm{min}$ are mainly responsible for higher number of thin places where as flat speed $360 \mathrm{~mm} / \mathrm{min}$ gives minimum number of thin places due to removal of higher number of short fibres and neps.

\subsubsection{Graphical Representation of Neps $(+200 \% / \mathrm{km})$ and Imperfection Index (IPI)}

In left sided graph of Figure 6, it was seen that at flat speed 240, 260, 280, 300 and $320 \mathrm{~mm} / \mathrm{min}$, neps $+200 \%$ are $357,332,315.2,301.2$ and 286 respectively which is a decreasing trend.

It is evident that at flat speed $240 \mathrm{~mm} / \mathrm{min}$ the numbers of the neps are higher and at $320 \mathrm{~mm} / \mathrm{min}$ the numbers of neps are lower. A decreasing trend of neps $+200 \%$ is found with the increase of flat speed.

The second graph of Figure 6 represents that the yarn spun at flat speed 320 $\mathrm{mm} / \mathrm{min}$ gives lower IPI than yarn spun at flat speed $240 \mathrm{~mm} / \mathrm{min}$.

The graph shows a decreasing trend of IPI with the increase of flat speeds of carding machine. 

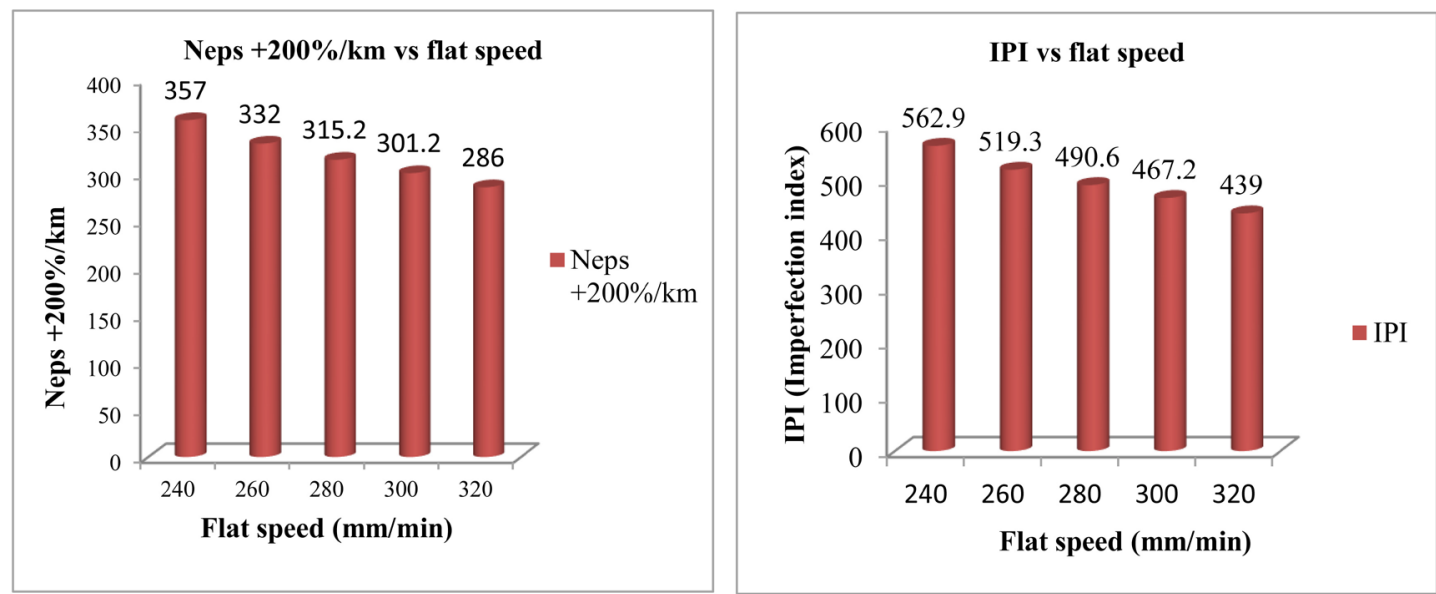

Figure 6. Effect of flat speed on neps $(200 \% / \mathrm{km})$ and imperfection index (IPI) of $40 \mathrm{Ne}$ cotton.

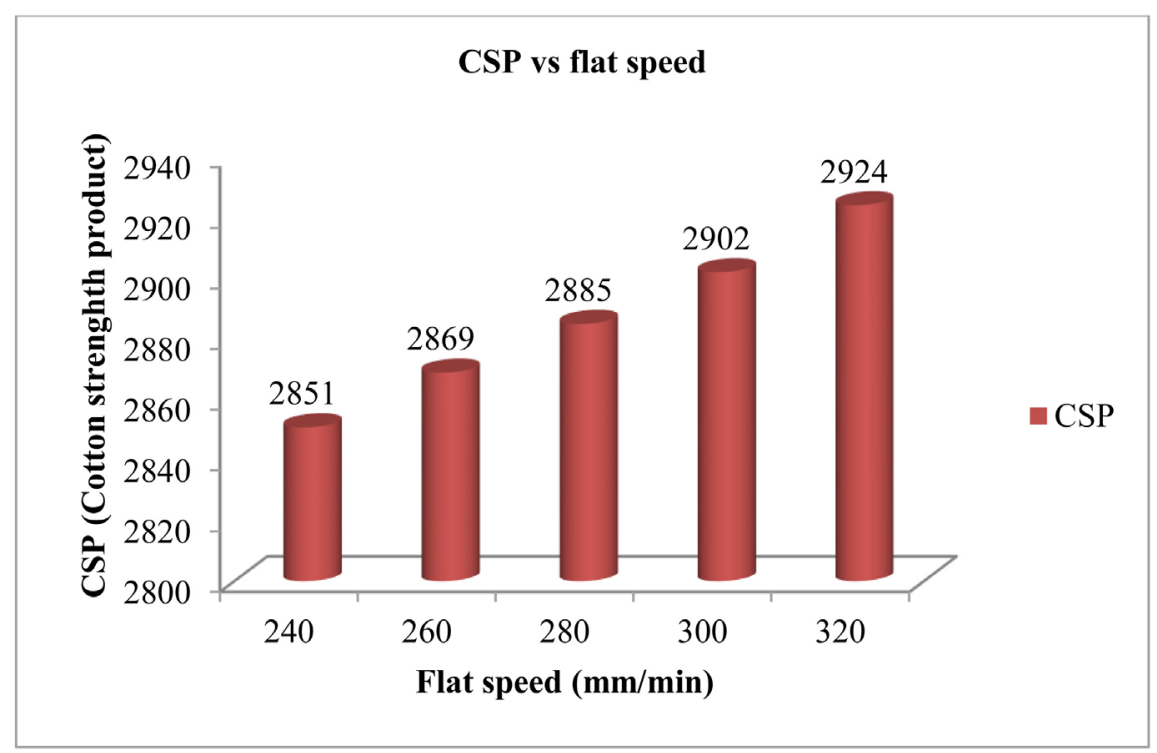

Figure 7. Effect of flat speed on count strength product of $40 \mathrm{Ne}$ cotton.

The decrease in total yarn imperfections with the increase of flat speed can be explained by amount of thick places, thin places and neps of yarn.

\subsubsection{Graphical Representation of Count Strength Product}

In Figure 7 the graph represents a significant effect on the strength with the increase of flat speed. It can be seen from graph 21 that the yarn C.S.P increases with the increase in flat speed. Excessive short fibres cause lower yarn strength. Graphs for short fibre content and neps content showed more neps and short fibres at flat speed $200 \mathrm{~mm} / \mathrm{min}$ than at speed $360 \mathrm{~mm} / \mathrm{min}$. Hence, a strength rising trend of C.S.P is found with the increase of flat speed

\section{Conclusion}

By this project work, the actual relationship between the flat speed and the yarn quality was studied. From the graphical representations, it may be concluded 
that with the increase in flat speed of card, more neps and short fibres are removed that results lower unevenness of card sliver. The quality of card slivers directly reflects the quality of yarns such as decreasing unevenness, imperfections and increasing the strength. The quality of yarn improves with the increase in flat speed and in this work, the highest flat speed i.e. $320 \mathrm{~mm} / \mathrm{min}$ is the optimum flat speed. There may be an optimum flat speed higher than $320 \mathrm{~mm} / \mathrm{min}$ after that yarn quality will start to decrease. Since we were restricted to use maximum flat speed at $320 \mathrm{~mm} / \mathrm{min}$, so obtaining optimum flat speed may be the topic of further research.

\section{Conflicts of Interest}

The authors declare no conflicts of interest regarding the publication of this paper.

\section{References}

[1] Klein, W. (2008) Manual of Textile Technology. The Textile Institute, Manchester.

[2] Atkinson, K., Harrowfield, B.V., Plate, D.E.A. and Robinson, G.A. (1986) Increasing Card Productivity. Journal of Textile Institute, 1.

[3] Dehghani, A., Lawrence, C.A., Mahmoudi, M., Greenwood, B. and Iype, C. (1999) Fibre Dynamics in the Revolving-Flats Card Part II: An Investigation into the Opening, Individualisation, Orientation and Configuration of Fibres during ShortStaple Carding. Journal of Textile Institute, 2, 78-87.

[4] Deussen, H. (1993) Improved Cotton Fiber Properties: The textile Industry's Key to Success in Global Competition. Proceedings-Beltwide Cotton Conferences (USA), New Orleans, January 10-14, 1993, 90-96.

[5] Artzt, B.P. (1997) The Special Structure of Compact Yarns-Advantages in Downstream Processing. ITB Yarn Fabric Forming, 2, 41-48.

[6] Nadim Hossain, A. (2017) Effect of Taker-in on the Quality of Ring Spun Yarn. Ahsanullah University of Science and Technology, 3, 11-12.

[7] Purushothama, B. (2011) A Practical Guide to Quality Management in Spinning. Woodhead Publishing 2011, India. https://doi.org/10.1533/9780857093950

[8] https://www.academia.edu/1848499/Yarn_Unevenness_and_its_Impact_on_Quality

[9] https://www.academia.edu/1848499/Yarn_Unevenness_and_its_Impact_on_Quality

[10] http://apparel-engineering.blogspot.com/2013/02/yarn-csp-test-count-strength-pro duct.html 